\title{
Glutaminase Family
}

National Cancer Institute

\section{Source}

National Cancer Institute. Glutaminase Family. NCI Thesaurus. Code C128179.

An enzyme family that cleaves amide bonds to generate glutamate from glutamine.

There are two human glutaminase genes that are expressed in a tissue specific pattern. 